\title{
Development and Future of the Department Store Industry in Taiwan
}

\author{
Hsiung-Shen Jung \\ Department of Applied Japanese, Aletheia University \\ Tamsui, New Taipei, Taiwan \\ au4210@mail.au.edu.tw
}

\begin{abstract}
In recent years, Taiwan's department store developed its management strategy from homogenization to differentiation, furthermore, to large-scale chain. Traders adopt to cooperate technically or financially, as its development characteristics. This article is for the origin of Taiwan's department store industry, progress and the overall economic environment, changes in consumer behavior on the department store industry of the discussion and analysis of the relevant industries on the development and research benefit. Nowadays, the development of mature large-scale Taiwan department store industry had expanded the territory to China. The big market, much consumer population of China will become a new world of Taiwan department store industry.
\end{abstract}

Keywords-Taiwan's department store industry, Foreign partners, Shopping mall, Discount store

\section{INTRODUCTION}

Since the government opened the foreign investment in the department store industry in 1987, the Japanese department store industry began to technically cooperate or joint venture stationed in the Taiwan market [1]. The mid80s, the Today's Department store cooperated with the Japanese Seibu Group first. Afterward, the joint venture department store in Japan under the guidance of Japan's strong capital and professional \& technical skills, made a rapid expansion of the limited market of department store. Now, Far East department store is the last one that still occupies quite a little share of local capital department store. Department stores are now facing to the competition with shopping mall, in addition to actively play their own functions and characteristics, should also strengthen the differentiation with the shopping Mall. In addition, due to the small population in Taiwan, and the market has been saturated, little room for development, experienced department stores have also been out of Taiwan and expanding overseas markets, but the growing spending power of the Chinese market is still a great room for development.

\section{RESEARCH AND ANALYSIS}

\section{A. The Development of Taiwan's Department Stores}

The development of department stores in Taiwan can be broadly divided into the following seven stages.

\section{1) Japanese era (1932 49):}

Taiwan's first department store was Kikumoto Department Store which founded in 1932. In 1945, after Taiwan recovered, received by the government, and later renamed "NanYang Department Store".

\section{2) The budding period (1949 65 years $)$ :}

After the recovery, the first department store in Taiwan is "JianHsin department store." In 1953 in Kaohsiung set up the "DaHsin Department Store", an important business philosophy for the implementation of "price" and "no price" campaign. Founded in 1965, "First department store", later renamed the "New First department store", is the first largescale comprehensive department store, to the domestic consumer supply-based, the first way to operate the counter, the goods classified according to industry categories. This is also the trend of leading department stores in Taiwan to another large integrated department store.

\section{3) Development period (1965 74$)$ :}

Since the national income was quite low, with high quality for the requirements of the department store was not very popular, so the government has also promoted several awards construction industry to invest in department store business policy. After 1966, tens of department stores opened one after another. At that time, enterprise groups have joined the business, but most of its business style was still following the traditional management of the past.

\section{4) Competition period (1974 81 years $)$ :}

This period is the stage of rapid economic development in Taiwan. The rapid rise in national income and the increase in spending power have led to the vigorous development of department stores in Taiwan. As the period of Taiwan's department store growth is too fast, coupled with the lack of business philosophy, similar products and similar demands, leading to the fierce competition in department stores, many department stores closed down.

\section{5) Metamorphosis period (1981 87):}

In 1987, under the approval of the Ministry of Economic Affairs to open overseas branches of department stores and services, the department stores and foreign investors (especially Japanese) were very popular and attracted the 
joint venture or technology Cooperation in the introduction of Japanese department store business philosophy.

\section{6) Innovation period (1987 97):}

During this period, changes in department stores such as: community and suburban department stores gradually increased. Changes in customer consumption: the proportion of increased sales outside the store, store membership card usage increased significantly.

\section{7) Modern period (1997 present $)$ :}

The establishment of the shopping mall also brought Taiwan's circulation industry into a new era. Large shopping malls provide more leisure space and activities than department stores. As the department store market is too saturated, in the department stores continue to compete and large-scale discount stores, shopping mall continue to develop, many department stores are re-starting way to restart, more is to change the type.

\section{B. The Function and Characteristics of Department Store}

According to the 9th revision of Directorate-General of Budget, Accounting and Statistics, Executive Yuan of the Republic of China Industry Standard Classification in 2009, the department store belongs to the 4751 department store industry under the wholesale and retail category of $F$ category. The department store industry is defined as "where the department stores are engaged in a variety of merchandise sub-sectors in the same place" [2].

Lin ZhengXiu and Wang MingYuan (1995) define the department store as a large retail business, usually living in a commercial center, with large buildings, a lot of departments, and a wide variety of goods sold. Its sales of goods, mainly through the sales service staff to explain and recommend to complete, so the price, often higher than the general store, in the store decoration, merchandise display, advertising, aftersales service, are the demands of sales points. In order to satisfy the consumer one-stop-shopping of the psychological, in general department stores are equipped with supermarkets, supply grocery, fresh and all kinds of fruit [3].

Taiwan's circulation industry is facing a great impact and innovation. For example, the convenience store, supermarkets gradually replaced the traditional small retailers by the convenience of goods, distance and time, got some share in the circulation market eventually. The rise of mass retailers, not only made the traditional wholesale industry decline, but due to its convenient parking, large floor space, rich assortment, low prices, and make these merits as a selling point in the circulation industry to develop better results. The department store industry is one of the many retail types, relative to the selling point of discount store, in the department store exquisite way of operation, each have their own market, but with the economic liberalization and international market promotion, foreign of the circulation industry more joint venture and technical cooperation, relying on its strong financial resources and superior business technology to squeeze into the Taiwan's market, giving the circulation industry pressure. Some of the existing department stores not only renewal the store itself, but the development of new business formats and the development of satellite shops has also become a major issue. Moreover, the pace of development of department stores is closely related to the degree of economic development in a country. It is boom or not of department stores is reflected in the level of national income and can display the degree of urbanization and the change of people's consumption habits.

Department stores emphasize their own style of goods, to provide consumers with comfortable leisure space, improve the entertainment facilities, subdivide the object customer layer, give discounts by using credit card upon consumption, etc. In addition to the renewal of the department store, how to expect the development of new business establishments and the development of satellite store, still remain to be a considerable subject [4].

Stern and EI-Ansary (1992) proposed that the department store have the following characteristics:

- Department stores are located in the central of the city or suburban shopping mall;

- Business approach to the chain;

- Sales of large and diverse types of products;

- In addition to providing the purchase of goods, but also to provide free services;

- Mainly operated apparel in early days, Customer base was mainly women;

- Sales of goods is larger than other circulation industry;

- Department store organization types typically take part of the system [5].

Department stores are one of the most innovative and influential business organizations. It affects many aspects of social and economic activity [6].

Yu Shunde, Jiang Hunqin (2008) use of geographical information system in the large shopping malls of the internal space characteristics of the value of Taiwan's department stores will be divided into four types of retail stores:

- Standard regional level shopping mall;

- Standard full line department store;

- The shopping mall operates management policy by the department store mode;

- The department store expands to the regional shopping mall [7].

\section{Taiwan's department store foreign partners}

Under the guidance of strong capital and professional and technical skills of Japan, Taiwan-Japan joint venture department store got the limited Taiwan department store market immediately with oligopoly. While the Asiaworld Department store, Evergreen Department store and other local capital of the department store companies have ended 
their business, and withdraw from the market. So far there is still the existence of the local capital department store, has almost been running out. In the Taiwan department store market still has a place, only the Far East Group belongs to the Far East Department Store. In the future, due to the withdrawal of the SOGO Group in Japan and the loss of the operating rights of the Pacific Group, the Pacific Sogo Department Store was taken over by the Far East Group to become a local capital department store. However, the name was not changed to the Far East Department Store, and even from Japan's LOGO is still in use. In fact, besides the company wants to continuously maintain the customer recognition is not easy to establish, although it is the actual Taiwan-funded department stores, the mentality that they want to continue the impression of Taiwanese to the Japanese brand and Japanese department store, should also be an important consideration.

Why the local capital of Taiwan's department store of foreign capital cooperation object is full of Japanese, there is no other foreign investment. This paper argues that the first is regional cultural factors. Asia, Taiwan and Japan due to subordinate relations caused by the colonial period of historical factors. Looking around Japanese department stores overseas branches are also almost in Asian countries. The second is the direct investment factor. Since World War II, the United States and Japan have always been the main foreign investment in Taiwan. But in Taiwan, there is no joint venture of department stores established between Taiwan and the United States, so the impact of this factor is limited in Japan. The third is customer acceptance factor. The products made in US or Japan are a symbol of high technology and quality. But the US products are mostly military or aerospace industrial products. Japanese products are mostly related to the general life of household appliances and daily necessities. Therefore, the Japanese products of daily necessities are mostly delicate and love, it's in line with Taiwanese preferences, personality, and even national character, so it gets high degree of acceptance of goods naturally.

After the wave of mid-80s Sino-Japanese joint venture department store, this century got into the wave of the Taiwan-funded-department-store-type large shopping mall. Such as the Breeze Square department store, Miramar Mall, Living Mall, Taipei 101 Department Store and Dream Mall in Kaohsiung. There are many reasons for the decline of the local capital department store. The strong competitiveness of the joint venture department store is the main reason, but the change of the regional business district is also an important reason. Such as Leber, Lailai, Lion, Today's and other Taiwan-funded department stores, these are all located in the western part of Taipei, crowded Ximending. But with the development of Xinyi planning area, making the eastern part of Taipei by the agricultural land or military land, completely reborn into a bustling commercial district, while moving the crowds from the west to the East.

As mentioned above, after the mid-80s Taiwan-Japan joint venture department store of the wave, Taiwan's department store market quickly saturated, and immediately formed the
Red Sea market. The change of regional business district is just brought the Western consumer population to the East, the total did not increase. Therefore, how to stop the killing of the Red Ocean market, to become the Blue Ocean market, and open up overseas markets is an important issue for all industry must face.

\section{Market Overview}

Taiwan's department stores are mainly located in the five metropolitan areas; but there's still some department store market join the competition among business districts alone. Has gradually in accordance with the size of shopping district and store size, the development of a new and polarized department store is "large and complete" chain of department stores; the other is "small and fine" Small \& medium-sized department stores or specialist.

The emergence of large shopping malls, speed up the department store towards large-scale, leisure development. Department stores in the consumption patterns, competitive environment and the development trend of change, there will be a fierce competition to be seen among many industries and outside of it in the future [8].

Taiwan's department store has two characteristics. First, by the introduction of the Japanese department store joint venture and business management model, and the market share is high, such as the Pacific SOGO, Shin Kong Mitsukoshi and so on. Second, Due to the need for new consumption patterns, has been toward the large, chainoriented group of operating oligopoly mode of competition, and small \& medium-sized department store operating pressure doubled, such as the Pacific, Shin Kong Mitsukoshi, Far East and other consortium of three consortia, and actively develop Large-scale chain system to achieve economic scale. Reduce costs, while seizing the advantages of access. So the department store has formed three pillars of the situation. On the other hand, under the circumstances of lack of competitiveness, small \& medium-sized department stores are facing to the decrease of the crowd and the gradual loss of performance due to narrow stores, lack of parking spaces, incomplete goods and services, and other unfavorable factors, causing difficulty of market space expansion and easiness of compressing result from these problems.

For the people live in the metropolitan area, due to the limits of destination, transportation and the time for their leisure, it is possible to provide department stores with the strongest and most versatile leisure places. Department store which provides holistic and multi-functional leisure place to the people became an attractive store. That's why more and more manufacturers have been strengthened the surrounding service and additional function. From Taiwan's market vision, powerful sales volume of metropolis department stores turn these manufacturers into competitors, throwing stones to clear the way for their own products. Therefore, they start to display famous brand products naturally. On the other hand, the local stores' popularity which covered in the district are less than the former, commodity composition must be adjusted in type, brand, and amount [9]. 
With the high growth of Taiwan's economy and the improvement of people's ability to earn higher income, the desire to go shopping is becoming stronger and stronger, also more and more often. This is seen as another new national recreational activity [10].

With the promotion of economic liberalization and internationalization, the foreign department store industry through a variety of joint ventures and technical cooperation. Relying on its strong financial resources and excellent business technology to enter the Taiwan's market, some of the department store $100 \%$ invested by Taiwan's local capital in early period is facing the pressure. Most of the department stores are looking for more foreign cooperative ventures to cope with increasingly fierce market competition. However, almost all of the industry had cooperated with foreign companies. In the case of hyper-high similarity, the market competition is more and more intense. So some industry has already set up branch store in China, but also faced with the strong competition among Chinese local industry.

\section{LITERATURE REFERENCES}

Lin Zhengxiu, Wang Mingyuan (1995) defines a department store as a large retail business, usually located in a commercial center, with large buildings, a large number of departments, and a wide variety of goods sold inside. Stern and EI-Ansary (1992) proposed the department store to have the following characteristics:

- Department stores are mostly located in the business center or suburban's shopping mall;

- Mostly operate by chain stores;

- Sales of large and diverse types of products;

- Besides provide the purchase of goods, also provide free services;

- mainly operated apparel in early days, Customer base was mainly women;

- Sales of goods is larger than other circulation industry;

- Department store organization types typically take part of the system.

Yu Shunde, Jiang Hunqin (2008) pointed the domestic department store-related retail shopping malls are divided into four forms:

- Standard regional level shopping mall;

- Standard full line department store;

- The shopping mall operates management policy by the department store mode;

- The department store expands to the regional shopping mall.

Zhao Yilong, Xu Xuwei (2013) thinking that the appearance of large shopping malls speeded up the department store towards large-scale, leisure development.
There will be a law of the jungle to be seen among department store industry. Chen Yaomao, Li Junming, Wu Jiaying (2009) pointed out that the quality of department store industry performance and domestic economic growth, consumer spending, the level of income and consumption patterns are closely related, and change with it.

Zhao Yilong, Xu Xuwei (2013) pointed out that the department store also provide people with food, visit the exhibition, performance appreciation, learning talent, and enjoy the film and other leisure activities. So the power gathering crowds are stronger. Zhang Hongsheng, Liu Xiaowei (2008) also thinking that shopping on the street is considered to be another emerging national leisure activities.

\section{CONCLUSION}

Taiwan's integrated merchandise retail industry in the emerging circulation industry, such as chain convenience stores, discount stores still grow and carve up the circulation industry market. Also, with the rise of full leisure function of the one-stop-shopping malls, although Taiwan's department store industries performance has increased year by year, the growth rate is quite limited, and the growth is much lower than the discount stores, chain convenience stores and other emerging circulation industry, making the position of department stores in the retail industry has gradually been eroding or crumbling. In order to correspond the new trend, with the new consumption patterns change, department store industry actively invest in the construction of upsizing, chain of department stores, resulting in some small \& mediumsized department store operators close their store due to the lack of competitiveness or close and transit some of their branch due to poor management.

Taiwan's department store industry has gradually saturated, a large number of promotions make profits become thinner instead. The business type should change with the trend, strengthen the market positioning of the partition. For example, make segmentation to the consumption time, like setting the business hours of department store located in center of the city, from Monday to Friday, while the main appeal of the shopping mall should be "satisfaction above full range of life," business hours should be the main weekend holiday and stressed the features "differentiation." Especially the goods, service quality and activities, should be differentiated from the large shopping mall to create a unique appeal. In conclusion, department store industry is growing thing with the national economic. On the other side, the national recession not only means that the department store industry is to be worried, also means that discount stores will be growing.

At the same time, the department store industry should jump out of the small, highly competitive Taiwan market, more positively get into Chinese market that there is the larger market, large consumer population. I believe, with years of experience and improvement the standard of living with the Urbanization policy, Taiwanese department store industry can follow the growth of Chinese economy and create success. 


\section{REFERENCES}

[1] De-Tai Fon, Tzu-Chin Tseng (2011), The Comparison on the Influence among Shopping Value, Brand Affect and Brand Commitment of Department Stores between Taiwan and Mainland China, Journal of Chinese Trend and Forward, 7 (1), 1-14

[2] Directorate-General of Budget, Accounting and Statistics, Executive Yuan (2011), Republic of China Industry Standard Classification (9th Revision)

[3] Lin Zeng Shiu, Wang Minh Yuan(1995). Modern retail management, H WA TAI Publishing

[4] Chen Shin Tsi(1995). Retail strategic information system. Unalis

[5] Stern, L. W., \& EI-Ansary, A. I. (1992). Marketing channels (4th ed.). Englewood Cilffs, New Jersey: Prentice-Hall.

[6] Tamila, R. D. \& Reid, S. E. (2007). Technological innovation and the rise of the department store in the 19th century. International Journal of Technology Marketing, 2 (2), 119-139.
[7] Shun-Te Yuo, Hun-Chin Chiang (2008), Micro-Spatial Analysis of Retail Agglomeration within Large-Scale Retail Properties-The Impact of Different Operation System to Retail Floorspace Allocation in Shopping Centres and Department Stores, Journal of Taiwan Geographic Information, 6,29-48

[8] JawYi-long, Hsu Hsu-wei (2013), Relationship between Environmental Complexity and Organizational Change in the Department Store Industry: A Case Study on M-Department Store and U- Brand, Marketing Commentary, 10 (2), 117-144

[9] Yow-mow Chen, June-Ming Li, Jia-Ying Wu (2009), The Position Analysis Studies on Planning Department Store Services for Improve Customer Satisfaction-Taichung Area as Example, Services Marketing Conference

[10] Chang Hong-sheng, Maggie Liu(2008), The Study of Marketing Strategy Trend in the Industry of Department Store in Taiwan, De Lin Journal, 22,357-372 